Jurnal Ilmiah Ibnu Sina, 6(2), Oktober 2021, 186-195

p-ISSN: 2502-647X; e-ISSN: 2503-1902

\title{
PHYSICAL STABILITY TEST AND ETHANOL CREAM IRRITATION TEST OF Moringa oleifera $\mathrm{L}$.
}

\author{
Nining Sugihartini ${ }^{1 *}$, Zainab $^{2}$, Aji Pamungkas ${ }^{3}$ \\ ${ }^{1}$ Laboratory of Technology Pharmacy, Faculty of Pharmacy, Universitas \\ Ahmad Dahlan, Yogyakarta \\ ${ }^{2}$ Laboratory of Phytochemistry, Faculty of Pharmacy, Universitas Ahmad \\ Dahlan, Yogyakarta \\ ${ }^{3}$ Undergraduate Program Study of Pharmacy, Faculty of Pharmacy, \\ Universitas Ahmad Dahlan, Yogyakarta \\ Email ${ }^{1}$ : nining.sugihartini@pharm.uad.ac.id \\ Email2: zainab@pharm.uad.ac.id \\ Email ${ }^{3}$ : ajipamungkas1880@gmail.com
}

Artikel diterima: 31 Maret 2021; Disetujui: 15 September 2021

DOI: https://doi.org/10.36387/jiis.v6i2.675

\begin{abstract}
The study aimed to determine the effect of variations the concentration ethanol extract cream of Moringa leaf of physical stability and irritability. Ethanol extract of Moringa leaves was obtained by maceration method with $50 \%$ ethanol solvent. The extract was formulated in cream type $\mathrm{O} / \mathrm{W}$ base with concentrations of $1 \%(\mathrm{~F} 1), 3 \%(\mathrm{~F} 2)$, and 5\% (F3). Creams were evaluated for physical stability including mechanical tests (centrifugation) and physical stability at room temperature $\left(25 \pm 2^{\circ} \mathrm{C}\right)$ with parameters $\mathrm{pH}$, viscosity on days $1,7,14,21$ and 28 . In addition, creams were also evaluated for their irritability in vivo with using test animals (rabbits). The data obtained were analyzed using one-way ANOVA test.

The results of the physical stability test showed that an increase in the concentration of Moringa leaf extract caused an increase in viscosity $(\mathrm{P}<0.5)$ and a decrease in $\mathrm{pH}(\mathrm{P}<0.5)$ but did not affect physical stability (mechanical test) and its irritating effect. F2 (1\%) has a $\mathrm{pH}$ of 7.61 while $\mathrm{F} 4(5 \%)$ is 7.01 . Based on the results of the study, it is concluded that variations in the concentration of ethanol extract of Moringa leaves can affect the physical stability of the cream and do not affect its irritation properties. Moringa leaf ethanol extract cream with a concentration of 5\% (F4) has physical stability and does not irritate the skin better than other formulas.
\end{abstract}

Keywords: Extract Of Moringa Leaves, Cream, Physical Properties Test, Irritation Test, Stability

\section{INTRODUCTION}

The leaves of Moringa (Moringa oleifera L.) has $\beta$ carotene levels of $0.24 \pm 0.01 \mu \mathrm{g} / \mathrm{ml}$; total phenolic $122.26 \pm 1.49 \mathrm{mg} / \mathrm{g}$ extract, total flavonoids $2.51 \pm 0.06 \% ; \mathrm{IC}_{50}$ antioxidant with DPPH $155.58 \mu \mathrm{g} / \mathrm{ml}$ method; tyrosinase enzyme inhibition 
Jurnal Ilmiah Ibnu Sina, 6(2), Oktober 2021, 186-195

p-ISSN: 2502-647X; e-ISSN: 2503-1902

$143.99 \mu \mathrm{g} / \mathrm{ml}$; SPF 24.75 \pm 0.11 (Sari, 2018). Moringa leaf ethanol extract has strong antioxidant and antithyrosinase activity because it contains flavonoids which can inhibit tyrosine activity in the process of melanin formation (Abidin et al., 2018). The activity of ethanol extract of moringa as antioxidant, sunscreen and antielastase is higher than extract ethanol of papaya fruit (Alimsyah et $a l, 2020)$.

Research on the formulation of Moringa leaf extract has been carried out that Moringa leaf extract can be used in topical treatment in the form of a cream dosage as a sunscreen and prevents aging (Atif et al., 2013). The other study (Nuryanti and Sugihartini, 2017) showed concentration of ethanol extract at $3 \%$ can be used to maintain evenness of skin. The concentration of ethanol extract affected the adhesivity, spreadability, $\mathrm{pH}$ and viscosity of cream in type O/W and W/O (Latif et al, 2020; Rikadyanti et al, 2020).

The choice of cream in this study has several advantages, including that it can be used to deliver drugs that show low water solubility, can be used to reduce irritation by formulating preparations in the form of an oil-in-water emulsion (Jones, 2008). The choice of cream type O/W is because it is easy to apply to the skin, is easy to wash off after being applied to the skin and has good spreading properties on the skin.

A cream preparation must meet physical stability requirements with $\mathrm{pH}$ and viscosity parameters because the stability of a substance is something that must be considered in making a formulation of a pharmaceutical preparation. Cream preparations are stable, that is, if they are within acceptable limits during the period of storage and use, that is, their properties and characteristics remain the same as they had at the time of manufacture. The presence of active substances is thought to affect the physical stability of cream formulations (Rosmala, 2014).

In addition, the use of creams on the skin can cause several reactions such as irritation, phototoxicity, contact allergies and photocontacts as well as contact urticaria. Irritation that occurs on the skin is influenced by several factors, including frequency 
Jurnal Ilmiah Ibnu Sina, 6(2), Oktober 2021, 186-195

p-ISSN: 2502-647X; e-ISSN: 2503-1902

of use, product composition/formula, concentration of ingredients/composition, use of certain ingredients, product penetration-enhancing compounds, location of product use, skin condition, contact time and the cumulative effect. To ensure that the cream preparations made do not irritate the skin, if used, it can be done by using an experimental animal irritation test (Windarwati, 2011).

Based on the description above, the basis for researchers to determine the effect of variations in the concentration of ethanol extract on physical stability with $\mathrm{pH}$ test parameters, viscosity test and to determine the in vivo irritation power of the ethanol extract cream of Moringa oleifera L. leaf.

\section{METHODOLOGI}

\section{Sample}

The samples used were Moringa oleifera L. leaves obtained from Pasar Beringharjo Yogyakarta and moringa leaf extract cream formulated in the Pharmacy Technology Laboratory of Ahmad Dahlan University Yogyakarta.

\section{Material and Equipment}

Materials in this study are extract leave of moringa, base of dosage form with pharmaceutical degree are cethyl alcohol, liquid parafin, stearic acid, Butylated Hydroxytoluene (BHT), glycerin, Trietanolamin (TEA), methyl paraben, prophyl paraben, aquadest. Six of rabbit was used in irritation test with $2 \mathrm{~kg}$ weight of body. Equipment in this study are rotary evaporation (Heidolph), vacuum pump (Rotary vanewater bath (Memmert), analytrical balance (Wiggen Hauser), $\mathrm{pH}$ meter semisolid (Laqua act), viskometer (Rheosys Merlin VR), mettler toledo HB43 moisture analyzer, glassware (Pyrex).

\section{Formulation of cream}

Cream is made by the melting method. In the first stage, materials in the water phase were carried out, namely Butylated Hydroxytoluene (BHT), glycerin, Triethanolamine (TEA), and methyl parabens. The ingredients are mixed and heated in aquadest at $75^{\circ} \mathrm{C}$ until dissolved. Then the next step is carried out for materials with an oil phase, namely stearic acid, cetyl alcohol, liquid 
Jurnal Ilmiah Ibnu Sina, 6(2), Oktober 2021, 186-195

p-ISSN: 2502-647X; e-ISSN: 2503-1902

paraffin, and propyl paraben. The materials are mixed and heated at a temperature of $75^{\circ} \mathrm{C}$. The third stage is mixing by mixing the oil phase gradually into the water phase mixture at a temperature of $75^{\circ} \mathrm{C}$ while stirring in a warm mortar. Stirring constantly. After the two phases are mixed, then the Moringa leaf extract is added gradually into the mixture while stirring until it is homogeneous and cooled at room temperature and forms a stable emulsion. Cool the cream while continuing to stir until homogeneous. The cream preparations that are formed are put into a closed container (Nuryanti, 2016).

Table 1. Formulation of extract leave moringa in cream type o/w (Suryati, 2015)

\begin{tabular}{lcccc}
\hline \multicolumn{1}{c}{ Ingredients } & $\begin{array}{c}\text { Formula } \mathbf{1} \\
(\boldsymbol{\%})\end{array}$ & $\begin{array}{c}\text { Formula } \mathbf{2} \\
(\boldsymbol{\%})\end{array}$ & $\begin{array}{c}\text { Formula 3 } \\
(\boldsymbol{\%})\end{array}$ & $\begin{array}{c}\text { Formula 4 } \\
(\boldsymbol{\%})\end{array}$ \\
\hline Extract leave of moringa & - & 1 & 3 & 5 \\
Liquid parafin & 10 & 10 & 10 & 10 \\
Cethyl alcohol & 1,5 & 1,5 & 1,5 & 1,5 \\
Stearic acid & 3 & 3 & 3 & 3 \\
BHT & 0,02 & 0,02 & 0,02 & 0,02 \\
Glycerin & 2 & 2 & 2 & 2 \\
TEA & 2 & 2 & 2 & 2 \\
Methyl paraben & 0,1 & 0,1 & 0,1 & 0,1 \\
Prophyl paraben & 0,05 & 0,05 & 0,05 & 0,05 \\
Aquadest ad & 100 & 100 & 100 & 100 \\
\hline
\end{tabular}

\section{Sentrifugation test}

The cream sample is put into a centrifugation tube then put into a centrifugator. Samples were centrifuged at $3750 \mathrm{rpm}$ for 5 hours. After centrifugation, it was observed whether there was separation or not. Testing is only done at week 0 (Rieger, 2000).

\section{Physical stability at room temperature $\left(25 \pm 2^{\circ} \mathrm{C}\right)$}

Cream samples were stored at room temperature $\left(25 \pm 2^{\circ} \mathrm{C}\right)$, then carried out organoleptic observations (changes in color, smell, and syneresis), $\mathrm{pH}$ measurements, and viscosity measurements. Observations were made on days 1,7 , 14, 21, and 28 (Iswandana and Sihombing, 2017).

\section{Test of pH}

$\mathrm{pH}$ determination is carried out using a pH meter. The trick: the tool is first calibrated with a standard buffer solution ( $\mathrm{pH}$ 7.01) and an acid buffer solution (4.01) until the tool 
Jurnal Ilmiah Ibnu Sina, 6(2), Oktober 2021, 186-195

p-ISSN: 2502-647X; e-ISSN: 2503-1902

shows the $\mathrm{pH}$ value. Then the electrodes are washed with water and dry with a tissue. The electrode is immersed in the solution. Let the tool show the $\mathrm{pH}$ value until constant. $\mathrm{PH}$ observations were carried out on days 1, 7, 14, 21, and 28. Measurements were made three times for each preparation (Erawati et al., 2016).

\section{Viscosity test}

The viscosity test of the cream preparations was measured using a Brookfield LV viscometer and a Rhemoeter (Rheosys merlin VR) with a 1/30 $\mathrm{mm}$ spindle parallel plate. The viscosity test was carried out by placing $50 \mathrm{mg}$ of the preparation on a plate and closed in parallel. Then run through a computer device with the Rheosys micra application. The measurement system, spindle speed, number of measuring points, measurement time intervals between points, and temperature are set to "test definition". Viscosity measurement starts with pressing start and lasts a certain time. The measurement parameters are set so that the formula experiences the same treatment (Hendriana, 2016).

\section{Irritation test}

The irritation cream test was carried out on rabbit test animals. Testing for acute dermal irritation is based on the provisions of the BPOM (2014) regarding guidelines for in vivo non-clinical toxicity testing. This test is used to determine the presence of an irritating effect on the skin as well as to assess and evaluate the characteristics of a substance when exposed to the skin. The test animals used were healthy and adult male or female albino rabbits, weighing about 2. The dosage used for liquid test preparations is as much as $0.5 \mathrm{~mL}$ and for solid or semi-solid test preparations as much as $0.5 \mathrm{~g}$ while the preparations in the form of containers and medical devices are extracted and prepared for test preparations. The test preparation is exposed to a skin area of $\pm 6(2 \times 3)$ $\mathrm{cm}^{2}$, then the location of exposure is covered with gauze and plastered with a non-irritant plaster. All test animals should be observed for the presence or absence of erythema and edema, response assessment carried out at 1 , 24,48 , and 72 hours after opening the 
Jurnal Ilmiah Ibnu Sina, 6(2), Oktober 2021, 186-195

p-ISSN: 2502-647X; e-ISSN: 2503-1902

patch (for non-corrosive/irritant test preparations).

\section{RESULT AND DISCUSSION}

\section{Making moringa leave extract}

Moringa leaf extract was made by maceration with $50 \%$ ethanol. The viscous extract of moringa leaves was obtained as much as $710 \mathrm{~g}$ and the yield of the extract obtained was $23.67 \%$.

\section{Making of cream}

The active ingredient used in this sunscreen cream is the extract of Moringa oleifera L. leaves with its constituent ingredients consisting of cetyl alcohol, liquid paraffin, stearic acid, Butylated Hydroxytoluene (BHT), glycerin, Triethanolamine (TEA), methyl paraben, propyl. parabens, and distilled water (Suryati, 2015), where these ingredients are often used in cream formulations. In making cream, Moringa leaf extract is added after the cream base is formed and the base temperature has started to decrease, with the aim that the active antioxidant compounds contained in the extract are not lost or damaged.
The oil phases in this formulation are stearic acid, cetyl alcohol, liquid paraffin, and propyl paraben because they have good baseforming and emollient characteristics in cream making. For the water phase selected Butylated Hydroxytoluene (BHT), glycerin, Triethanolamine (TEA), methyl paraben. TEA is used as an emulgator because TEA will form an $\mathrm{O} / \mathrm{W}$ emulsion which is very stable when combined with free fatty acids. A suitable free fatty acid is stearic acid because stearic acid will react with TEA in situ to produce a salt, namely triethanolamine stearate which functions as an emulgator (Aulton, 2002).

The use of emulgators to prevent coalescence, namely the union of small droplets into one separate single phase (Pratama and Zulkarnain, 2015). Liquid paraffin is used as an emollient that maintains the stability of the mixture of oil and water phases in cream preparations, cetyl alcohol in the $\mathrm{O} / \mathrm{W}$ emulsion can increase stability and can increase the consistency of cream (Unyala, 2009). Methyl paraben and propyl paraben function as preservatives and 
Jurnal Ilmiah Ibnu Sina, 6(2), Oktober 2021, 186-195

p-ISSN: 2502-647X; e-ISSN: 2503-1902

antimicrobials. Glycerin is used as a

Physical stability tests include humectant that keeps the skin moist when the preparation is applied to the skin and BHT is used as an antioxidant to delay or prevent the oxidation of fat in creams (Anonim, 1995). After forming a cream with various extract concentrations of $1 \%$, $3 \%, 5 \%$ and base (without extract), then the physical stability and mechanical testing (centrifugation) and physical stability at room temperature $\quad\left(25 \pm 2^{\circ} \mathrm{C}\right) \quad$ with parameters of $\mathrm{pH}$, viscosity on days 1 , $7,14,21$ and 28.

\section{Result of Sentrifugation test}

Result of sentrifugation test showed that the cream is stable as shown in Table II. irritation tests were carried out.

Tabel 2. Result of sentrifugation test $25^{\circ} \mathrm{C}$

\begin{tabular}{cll}
\hline Cream & \multicolumn{1}{c}{ Beginning } & Final \\
\hline F1 & There is no phase separation & There is no phase separation \\
F3 & There is no phase separation & There is no phase separation \\
F4 & There is no phase separation & There is no phase separation \\
& There is no phase separation & There is no phase separation \\
\hline
\end{tabular}

\section{Result of pH test}

The increasing concentration of the ethanol extract of Moringa leaves in the cream, the lower the $\mathrm{pH}$ value of each cream. This is related to the active substance contained in the ethanol extract of Moringa leaves, namely compounds such as polyphenols, flavonoids, and ascorbic acid which are acidic (Sugihartini et al, 2020). The decrease in $\mathrm{pH}$ during storage can occur due to the influence of $\mathrm{CO}_{2}$, because $\mathrm{CO}_{2}$ can react with the water phase to produce acids. This can be due to the fact that the packaging or container used is not impermeable, allowing air or gas to enter.

\section{Result of Viscosity test}

The viscous value is influenced by the thickening agent, the selected surfactant, the proportion of the dispersed phase and the size of the particles (Martin et al., 2008). When the preparation has a consistency that is too thick, the active substance will be difficult to separate from the base of the preparation and difficult to apply to the skin because it is difficult to stick, while if the preparation is too 
Jurnal Ilmiah Ibnu Sina, 6(2), Oktober 2021, 186-195

p-ISSN: 2502-647X; e-ISSN: 2503-1902

watery it will reduce contact with the skin so that drug absorption is not optimal. According to SNI 16-43991996, the ideal viscosity value of a sunscreen cream is $2.000-50.000 \mathrm{cps}$. The viscosity test of the Moringa oleifera L. leaf extract cream was performed using a Brookfield LV viscosimeter. Determination of the viscosity of the cream preparations was carried out for 28 days with the observation time, namely the $1^{\text {st }}, 7^{\text {th }}$, $14^{\text {th }}, 21^{\text {st }}$ and $28^{\text {th }}$ day.

\section{Result Irritation test}

Based on the data on rabbit skin smeared with formula I, formula II, formula III, formula IV and control gauze, the irritation score (primary irritation index) is 0 . The score can then be compared with the irritation response category in rabbits. From these data, it can be seen that the cream and cream bases with the addition of $1 \%, 3 \%, 5 \%$ Moringa leaf extract made in this study did not cause irritation to rabbit skin and were included in the negligible response category (very mild). It is hoped that with the irritation test, the ethanol extract of Moringa leaves cream on human skin is safe and comfortable and does not cause irritation to the skin when used.

\section{CONCLUSION}

1. The variation in the concentration of ethanol extract of 50\% Moringa oleifera L. leaf has an effect on the physical stability of the cream preparations. The greater the extract concentration added, the greater the viscosity but the smaller the $\mathrm{pH}$ value of the cream preparations.

2. The variation in the concentration of ethanol extract of $50 \%$ Moringa oleifera $\mathrm{L}$. leaves did not affect the skin irritation of experimental animals. The greater the concentration of Moringa leaf extract added to the preparation did not cause irritation to the skin of the test animals.

3. Formula III, namely cream with the addition of Moringa oleifera L. leaf extract $3 \%$ has a good physical stability of the cream compared to other formulas with organoleptic test parameters, vsicosity, $\mathrm{pH}$ and centrifugation 
Jurnal Ilmiah Ibnu Sina, 6(2), Oktober 2021, 186-195

p-ISSN: 2502-647X; e-ISSN: 2503-1902

test (mechanical) and does not

cause irritation to the skin of the

test animals.

\section{AKNOWLEDGEMENT}

This study was supported by grant from LPPM UAD in 2020.

\section{REFFERENCES}

Abidin, Z, Khaeriah, U, Zuhrina Z, Pratama, M, \& Baits, M, 2019, Tyrosinase Inhibitor Activity Measurement of Crude and Purified Extract of Moringa Leaves (Moringa oleifera L.), Indonesian journal of Pharmaceutical Science and Technology, l(1), 52-58.

Alimsyah, F, Sugihartini, N, Susanti, H, 2020, Optimasi Campuran Ekstrak Etanol Buah Pepaya (Carica papaya L.) dan Ekstrak Etanol Daun Kelor (Moringa oleifera) dalam Krim sebagai Antiaging, Jurnal Kesehatan STIKES Darul Azhar Batulicin, 9(1): 23-29

Anonim, 1995, Farmakope Indonesia Edisi 4, Departemen Kesehatan Republik Indonesia, Jakarta.

Anonim, 2014, Pedoman Uji Toksisitas Non-Klinik Secara In-Vivo, Badan Pengawas Obat dan Makanan RI, Jakarta.

Atif, A, Akhtar, N, Mumtaz, A.M, Khan, M.S, Iqbal, F.M, and Zaidi. S, 2013, In Vivo Skin
Irritation Potential of a Cream Containing Moringa oleifera L. Leaf Extract, American Journal of Pharmacy and Pharmacology, 7(6): 289-293.

Aulton,

M.E, 2002 ,

Pharmaceutics:The Science of Dosage Form Design, $2^{\text {nd }}$ Ed, Churchill Livingstone, Edinburgh, New York

Erawati, E, Pratiwi, D, Zaky, M, 2016, Pengembangan Formulasi dan Evaluasi Fisik Sediaan Krim Ekstrak Etanol 70\% Daun Labu Siam (Sechium edule (Jacq.) swatz), Farmagazine, 3(1).

Hendriana, P.V, 2016, Pengaruh CMC-Na sebagai Gelling Agent dan Propilen Glikol sebagai Humektan Terhadap Sifat Fisik dan Stabilitas Fisik Gel Ekstrak Pegagan (Centella asiatica (L.) Urban), Skripsi, Program Studi Farmasi Fakultas Farmasi Universitas Sanata Dharma, Yogyakarta.

Iswandana R, Sihombing L.K.M, 2017, Formulasi Uji Stabilitas Fisik dan Uji Aktivitas Secara In Vitro Sediaan Spray Antibau Kaki yang Mengandung Ekstrak Etanol Daun Sirih (Piper betle L), Pharm Sci Res, Vol.4 No.3, pp: 121-131.

Jones, D, 2008, Pharmaceutical Dosage Form and Design, Pharmaceutical Press, London.

Latif. A.R, Sugihartini, N, Guntarti, A, 2020, Sifat Fisik Krim Tipe $\mathrm{A} / \mathrm{M}$ dengan Variasi

Nining Sugihartini, dkk | 194 
Jurnal Ilmiah Ibnu Sina, 6(2), Oktober 2021, 186-195

p-ISSN: 2502-647X; e-ISSN: 2503-1902

Konsentrasi Ekstrak Etanol Daun Kelor Moringa oleifera Menggunakan Emulgator Tween 80 dan Span 80, Media Farmasi, XVI (1): 9-17

Martin, A, Swarbrick, J. \& Cammarata, A, 2008, Farmasi Fisik, Edisi Ketiga, Penerbit UI Press, Jakarta.

Nuryanti, Evi, 2016, Formulasi Krim Ekstrak Daun Kelor (Moringa oleifera L.) sebagai Sediaan Pelindung Kulit, Skripsi, Fakultas Farmasi Universitas Ahmad Dahlan, Yogyakarta.

Nuryanti, E dan Sugihartini, N, 2017, Formulation Cream of Extract Moringa oleifera Leave as Antiaging, Berkala Ilmu Kesehatan Kulit dan Kelamin, 29(1): 1-7

Pratama, W.A, Zulkarnain, A,K, 2015, Uji SPF In Vitro dan Sifat Fisik Beberapa Produk Tabir Surya yang Beredar di Pasaran, Majalah Farmaseutik, 6(1)

Rieger, M, 2000, Harry's Cosmetology, 8th ED. Chemical Publishing Co Inc, New York (US).

Rikadyanti, Sugihartini, N, Yuliani, S, 2020, Sifat Fisik Krim Tipe M/A Ekstrak Etanol Daun Kelor [Moringa oleifera L] dengan Variasi Konsentrasi Menggunakan Emulgator Asam Stearat dan Trietanolamin, Media Farmasi, XVI (1) : 88-96
Rosmala, Dewi, Effionora, Anwar, Yunita, K.S, 2014, Uji Stabilitas Fisik Formula Krim yang Mengandung Ekstrak Kacang Kedelai (Glycine max), Pharm Sci Res, 1(3), 194-208.

Sari, D, E, M, 2018, Uji Aktivitas Antiaging dan Penghambatan Enzim Tirosinase dari Ekstrak Etanol Daun Kelor (Moringa oleifera L.) secara In Vitro, Tesis, Program Pasca Sarjana Universitas Ahmad Dahlan, Yogyakarta.

Sugihartini, N., Jannah, S. \& Yuwono, T., 2020. Formulasi Gel Ekstrak Daun Kelor (Moringa oleifera Lamk) Sebagai Sediaan Antiinflamasi.

Pharmaceutical Sciences and Research, 7(1): 9-16

Suryati, Lucida, H, Dachriyanus, 2015, Formulation of Sunscreen Cream of Germanicol cinnamate from the Leaves of Tabat barito (Ficus deltoides Jack) and an Assay of its' Sun Protection Factor, International Journal of Pharmaceutical Sciences Review and Research, 32(1): 104-107.

Windarwati, S, 2011, Pemanfaatan Fraksi Aktif Ekstrak Tanaman Jarak Pagar (Jatropha Curcas Linn.) sebagai Zat Antimikroba dalam Sediaan Kosmetik, Tesis, Sekolah Pascasarjana Institut Pertanian Bogor, Bogor.

Nining Sugihartini, dkk | 195 